\title{
Factors Affecting the Growth and Development of SMEs: Experiences from Kosovo
}

\author{
Arbiana Govori \\ Public University "Haxhi Zeka", Peja, Kosovo \\ govoriarbiana@gmail.com
}

\section{Doi:10.5901/mjss.2013.v4n9p701}

\section{Abstract}

Small and medium enterprises are becoming increasingly important for the creation and development of a modern, dynamic and knowledge-based economy. This is because of their capacity to promote entrepreneurship and entrepreneurial skills, and because of their ability to be flexible and adapt quickly to a changing market, and to generate new jobs. SME sector is the backbone of the economy in countries with higher income, while it is less developed in the countries with the low incomes. Organization for Economic Cooperation and Development (OECD) reports that more than 95\% of enterprises in the OECD area are SMEs. These enterprises employ about $60 \%$ of private sector workers, make a major contribution in the field of innovation and support regional development and social cohesion. Also, SMEs in most low income countries give significant contribution to GDP growth and the creation of new jobs. In Kosovo SMEs represent more than $99 \%$ of the total number of enterprises and their share in GDP amounts to more than 50\% (CBK, 2011). For this reason, the identification of external factors affecting the development of SMEs in Kosovo is very important, in order to take all the necessary steps to reduce or remove barriers and create new opportunities for these enterprises. This research focuses primarily on the impact of external factors, with special emphasis on access to finance for Small and Medium Enterprises (SMEs) in Kosovo. External factors such as access to finance, competition, corruption, and government policies have very important impact in the development of SMEs in Kosovo. Facilitating access to finance is essential to set up a favorable environment to develop SMEs. However, in general, SMEs in developing countries face numerous barriers to funding, although this problem is not unknown even in developed countries. Barriers that face SMEs usually relate to high administrative costs, high collateral requirements and the lack of willingness of banks to lend to SMEs. Raising the level of awareness of their role and availability of access to finance for SMEs can improve economic conditions in developing countries by promoting innovation, growth of GDP and reduce unemployment.

Keywords: Small and medium enterprises, the SME sector, SME financing, development factors, bank loans, GDP.

\section{Introduction}

Although nowadays small and medium enterprises are an essential part of the economic structure in developed countries and developing countries, and play an important role in bringing the innovation, economic growth and prosperity, unfortunately, SME access to capital to fund their growth and expansion is very limited and for most of SMEs in developing countries represents a major obstacle. It is likely that SMEs do not have access to loans issued by banks, or face extremely unfavorable conditions of loans. On the other hand banks in developing countries have difficulties in lending activity as a result of imperfect or complete lack of information. As a result there is shortage of a genuine capital market for SMEs (Nichter \& Goldmark, 2009).

Many small businesses start out as an idea and mainly by one or two individuals who invest from its own resources and in some cases borrow from family and friends. But if they succeed, the time comes when all emerging/developing SMEs are in need for new investments to expand their operations or bring new innovations. Usually at this stage SMEs face problems because they have much more difficulties than large enterprises to provide financing either from banks or other sources. If SMEs can not obtain the necessary financing, it may happen that many brilliant ideas never be realized resulting in loss of potential for economic development (OECD, 2006).

Because of the political situation during the last few decades Kosovo has faced stagnation in the development of small and medium enterprises and consequently to the overall economic development. This research focuses primarily on the impact of external factors, with special emphasis on access to finance for Small and Medium Enterprises (SMEs) in Kosovo.

Another problem we face when we study the development of SMEs is the way of measuring the development. 
There is no a general approach on how to measure the development of enterprises, for this reason researchers use various indicators to measure it (Barkham et al., 1996). However, some of the variables that researchers use much more are increase of employment, sales and revenues for a specific period of time, because the collection of those data and their measurement is easy and simply (Delmar et al., 2003). Even for this paper have been used the same primary indicators for measuring the development of enterprises.

In this paper we will try to identify the factors that influence the growth and development of SMEs in Kosovo. In this context we analyze the impact of external factors that most influence the development of SMEs in Kosovo and the importance of bank credit to SME development in Kosovo.

\section{Theoretical approaches and definition of SMEs: Literature Review}

The term "SME" includes a wide range of definitions. Organizations, as well as various countries establish their definitive guidelines for categorizing SMEs, often based on sales, number of employees, or the value of assets. The World Bank defines SMEs as enterprises with a maximum of 300 employees, 15 million dollars in annual revenue and 15 million dollars in assets. Meanwhile the definition of the European Union states: "Micro, small and medium enterprises are those that employ fewer than 250 persons and which have an annual turnover not exceeding EUR 50 million and / or an annual balance sheet not exceeding 43 million Euros". In this way small and medium enterprises are defined as enterprises with 10 to 250 employees, and more than EUR 10 million turnover or EUR 10 million annual balances. This definition is more inclusive, especially in terms of turnover, compared with some other definitions.

Table 1: The definition of micro, small and medium enterprises according to EU

\begin{tabular}{|cccc|}
$\begin{array}{c}\text { Category of } \\
\text { enterprise }\end{array}$ & $\begin{array}{c}\text { Number of } \\
\text { employees }\end{array}$ & Turnover & Balance Sheet \\
\hline Medium & $<250$ & $\leq € 50$ million & $\leq € 43$ million \\
\hline Small & $<50$ & $\leq € 10$ million & $\leq € 10$ million \\
\hline Micro & $<10$ & $\leq € 2$ million & $\leq € 2$ million \\
\hline
\end{tabular}

Source: EU Commission, (2003). Recommendation 2003/361/EC.

According to Morrison (2006), enterprises are affected by external macroeconomic environment that can not be controlled, such as the political environment, economic, social, technological, environmental and legal factors. These factors are rarely affected by management decisions because they are external factors and beyond the control of SMEs. Among the main external factors that affect the development and growth of SMEs is access to finance, not neglecting here the other factors such as corruption, competition, government policies etc.

Lack of capital or denial to financial resources was a major barrier for SMEs and entrepreneurs, which usually have to mobilize their own capital or their own resources to establish or expand their business. Also, SMEs in developing countries have difficulties in accessing bank loans as a consequence to the high risk for failing loans, low profitability and lack of collateral required by banks (Harvie, 2005).

\subsection{Measuring the growth and development of SMEs}

To measure the development and growth of SMEs are used different indicators. Usually are used indicators such as sales or turnover growth and increase of employment over a period of time. Also for measuring the development of SMEs are used additional indicators such as asset value, market share, profits and output, though they are not very common compared with sales and employment indicators. Indicators such as the level of production and market share vary widely depending on the industry and as a result it is very difficult to use them for comparisons, while profit is not relevant unless measured for a period of time. For this reason both sales and employment remain very important indicators for measuring the growth and development of enterprises. Data on the number of employees is usually easier to collect as they are much more important for the government. On the other hand sales may be affected by inflation and it is very important to use several indicators together to study the growth and development of enterprises. (Davidsson et al., 2006). 


\subsection{External factors affecting the development of SMEs}

Enterprises are affected by external macroeconomic environment that can not be controlled such as political, economic, social, technological, environmental and legal factors (Morrison (2006). As already mentioned above, these factors can rarely be affected by management decisions because they are external factors beyond the control of SMEs.

\subsubsection{Access to finance}

The first challenge is the financial constraints. Lack of capital or financial resources was a major barrier for SMEs and entrepreneurs who usually have to mobilize their own capital or their own resources to establish or expand their business (Harvie, 2005). In addition, SMEs in developing countries have difficulties in accessing bank loans as a consequence to the high risk for failing loans, low profitability and lack of collateral required by banks (Harvie, 2005).

For many SMEs from countries in the region access to finance and capital appear to be difficult. This comes as a consequence of weak banking institutions, lack of capital market and inefficient legal framework regarding credit and collateral assessment. Financing of SMEs and access to finance plays a crucial role in the growth process and development of the enterprises. (WB, 2011).

\subsubsection{Competition}

By entering the competition, the company tries to find competitive advantages that greatly affect the success of the enterprise (Walley, 1998). SMEs are usually not very competitive in terms of market knowledge, innovation, prudent investment, business operations and good management, which are important factors in improving the quality (OSMEP, 2007).

Developing countries compete with other countries as a result of globalization and increased trade however barriers and other restrictions generally favor these countries (Lind, 2009). Competition is increasing by international companies as a result of the Free Trade Agreements (OSMEP, 2007). A survey of SMEs in developing countries was carried out by the World Bank. According to the findings of research competition represents a risk for survival for individual enterprises. Although competition represents high risk, it is the one who pushes companies towards higher productivity which actually results in their growth and development. During the last decade many researches have been carried out regarding the barriers faced by SMEs in Kosovo. The main barriers have been "Unfair competition" that includes tax system, the informal economy and public services, barriers which continued with the same intensity throughout the postwar period (WB, 2010).

\subsubsection{Government policies}

The importance of SMEs to the economy of a country indicates how important it is to have government policies that support SMEs, including regulations that enable them to operate efficiently and regulations that reduce their administrative costs (Harvie and Lee, 2005). Although there have been initiatives by governments to promote and support SMEs in order to enhance their development and reduce poverty, there is still a lack of laws and genuine administrative procedures such as accessibility to assistance from the government agencies (Harvie, 2005).

According to World Bank research, complex tax systems, low level of trust in the judicial system, and the need to pay bribes to access public services, represent major barriers, especially in South East Europe (WB, 2000).

\subsection{SME sector in the global economy}

SME sector is the backbone of the economy in countries with high income, but this sector is less developed in countries with low income. 
Figure 1: Contribution to employment

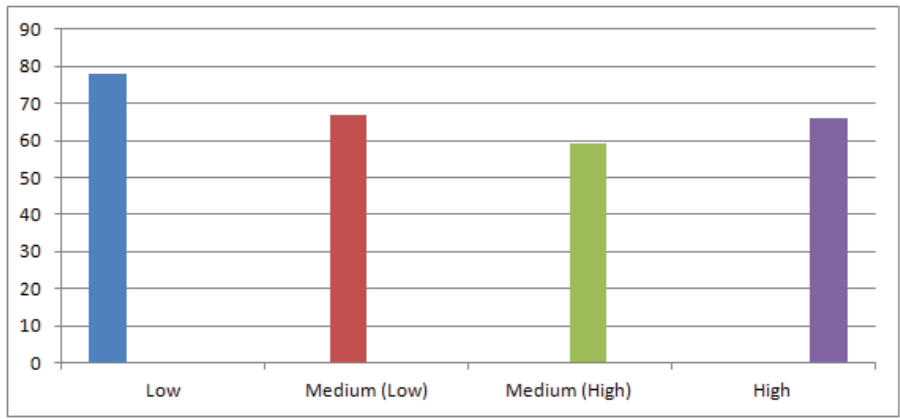

Source: World Bank (2011)

Organization for Economic Cooperation and Development (OECD) reports that more than 95\% of enterprises in the OECD area are SMEs. These enterprises employ about $60 \%$ of the total employees in the private sector, and provide a major contribution in the field of innovation, supporting regional development and social cohesion. Also, SMEs in most countries with low income give significant contribution to GDP and employment.

\section{Small and medium enterprises in Kosovo}

In Kosovo, more than $99 \%$ of enterprises belong to the SME sector, where most of them are focused on the retail sector being characterized with small and unproductive investments. (Strategy for SME development in Kosovo, 2011).

Table 2: Enterprises registered in Kosovo, based on the number of employees - 2010

\begin{tabular}{|cccc|}
$\begin{array}{c}\text { Category of } \\
\text { enterprise } \\
\text { Large }\end{array}$ & $\begin{array}{c}\text { Number of } \\
\text { employees }\end{array}$ & $\begin{array}{c}\text { Number of } \\
\text { enterprises }\end{array}$ & Percentage of total \\
\hline Medium & 50 or more & 58 & 0.06 \\
\hline Small & $10-49$ & 221 & 0.22 \\
\hline Micro & $1-9$ & 1,406 & 1.35 \\
\hline Total & & 102,070 & 98.37 \\
\hline
\end{tabular}

Source: Strategy for SME development in Kosovo, ARBK, 2011

According to data from the Agency for Registration of Businesses in Kosovo, at the end of 2010 have been registered more than 100 thousand SMEs, with 216.799 employees or about $89 \%$ of private sector employees and $62 \%$ of the total number of employees in Kosovo. It should be noted that in Kosovo enterprises according to law no. 2005/02-L5 are categorized only based on the number of employees. This categorization differs from the European Union countries, where in addition to the number of employees is taken into account the annual turnover and balance sheet as presented in Table 1.

From the data presented above, Table 2, we see that from the 103,755 enterprises 102,070 (or 98.37\%) are micro enterprises, $1,406(1: 35 \%)$ small, $221(0.22 \%)$ medium, and only $58(0.06 \%)$ are categorized as a large. In terms of sectors, SMEs are concentrated mainly in commerce with about 50\%, transport, storage and distribution (14\%), food products, beverages and tobacco (9\%) and hotels and restaurants (9\%).

And regarding the ownership of companies in Kosovo, individual companies lead by $90 \%$ while the rest are general partnership by 3.2\% and limited liability companies 5.8\%. (Agency for Registration of Businesses in Kosovo, 2011). 


\subsection{SME contribution to Gross Domestic Product (GDP)}

As mentioned earlier the role of SMEs in the economy of a country is very important. In addition to the positive impact on other aspects such as the reduction of unemployment and poverty alleviation, they have an even greater impact on GDP growth of a country. Based on data from the Tax Administration of Kosovo (TAK), presented in Table 3 below, the total turnover of SMEs in 2010 was more than 2.2 billion which represents $56.81 \%$ of GDP.

Table 3: Participation of SME turnover in GDP

\begin{tabular}{|ccc|}
\hline Size of enterprises & Turnover & Participation in GDP (\%) \\
\hline Micro & $656,885,164.33$ & 16.79 \\
\hline Small & $667,585,914.82$ & 17.07 \\
\hline Medium & $369,455,655.16$ & 9.44 \\
\hline Large & $528,558,359.84$ & 13.51 \\
\hline Total & $\mathbf{2 , 2 2 2 , 4 8 5 , 0 9 4 . 1 5}$ & $\mathbf{5 6 . 8 1}$ \\
\hline
\end{tabular}

Source: Tax Administration of Kosovo (2011): Annual report of the SME.

However, a problem that remains to be resolved is the informal economy, which according to the "Government program to prevent informal economy in Kosovo 2011-2012" constitutes from 39 to 50\% of GDP. On this issue was discussed by all levels of the country and is expected to continue with practical steps for quickly reduction of this phenomenon to an acceptable extent as the complete elimination is almost impossible.

\section{Analysis of external factors affecting the development of SMEs in Kosovo}

\subsection{Access to finance}

According to Nichter and Goldmark (2009) policies favor large enterprises while small enterprises face problems and difficulties to their development as a consequence of lack of access to finance. SMEs usually have difficulties to develop as a consequence of lack of collateral, high transaction costs and the inability to deal with complex financial institutions formalities. This is confirmed by our literature review according to which SMEs face difficulties in obtaining loans because they are seen as high-risk enterprises.

Enterprises studied in this research have started their business with financing from their internal resources. This happens with almost all new enterprises which have difficulties to access external financing. From the data generated we understand that obtaining loans for entrepreneurs in Kosovo is very difficult. The problems that usually face SMEs are lack of collateral and the unwillingness of banks to finance small enterprises, especially those new established. But for business expansion, in our case SMEs have received loans, and this is because they have managed to prove and establish their financial history.

\subsection{Competition}

One other factor that affects the growth and development of SMEs in Kosovo is the competition. Many companies of the region and beyond produce products similar to those of Kosovo enterprises. Procedures and costs of starting a business presses entrepreneurs to avoid investments or to join the informal economy. These barriers result in weaker competition, unfair competition and adversely affect investments (World Bank 2010).

Surveyed enterprises have assessed unfair competition as an obstacle to the development of SMEs in Kosovo. Also, the attitude of consumers towards local products being associated with a lack of confidence in the quality of these products is a negative phenomenon in the development of these enterprises, making imported products to be much more desired which can be proven by the negative trade balance of Kosovo.

\subsection{Corruption}

In many socio-economic areas there are problems and one of them is corruption. Long-term consequences of corruption 
in transition economies and developing countries can be very harmful. Kosovo still faces numerous challenges in infrastructure and economic development policy. In recent years many improvements have been made but should still be done to minimize corruption (Riinvest, 2002).

In 2011 according to "Transparency International" Corruption Perceptions Index (CPI) for Kosovo was 2.9 by ranking it as 112th out of 182 in total. Corruption Perceptions Index (CPI) is related to perceptions of the degree of corruption among public officials and politicians by entrepreneurs and business people as well as country analysts. CPI rate starts with 10 (completely clean) to 0 (highly corrupted). Kosovo in this list has marked a decline since 2009 (Transparency International, 2011).

According to research corruption as phenomenon exists in all developing countries. The fight against corruption seems impossible especially in a country with the highest rate of poverty in Europe. In Kosovo, the level of corruption remains high and this requires more commitment by the government in continued reduction until the total elimination of this phenomenon. In addition to problems with infrastructure, administrations, as well as other services such as electricity and water everyday make difficulties for businesses and citizens. As a consequence of corruption practices in other countries have shown that this phenomenon negatively affects the investment, whether foreign or domestic.

\subsection{Government policies}

Besides corruption and unfair competition there are problems with the judicial system and the implementation of laws and regulations by governmental bodies which adversely affect the business of the enterprise. These are seen as obstacles to doing business according to the World Bank Report, where Kosovo is listed at the bottom of the list since many years (WB, 2012). However, in recent years there was a tendency to push things forward, and to make Kosovo a more attractive place for doing business. The results of these efforts are expected to be seen in the future, where one of the indicators will be the ranking in the list of World Bank "Doing Business" which is published in the last months of the year.

\section{The importance of bank credit to SME development in Kosovo}

Banking system in Kosovo is considered as one of the main promoters of economic activity, reaching in total value of 2.5 billion Euros, or $52.8 \%$ of GDP, the assets managed by them. This has come mainly by loans and investments in securities. (CBK, 2011).

Table 4: The structure of banking system assets

\begin{tabular}{|l|c|c|c|c|c|c|}
\hline \multirow{2}{*}{ Description } & \multicolumn{2}{c|}{ June 2009 } & \multicolumn{2}{c|}{ June 2010 } & \multicolumn{2}{c|}{ June 2011 } \\
\cline { 2 - 8 } & Million Euros & $\begin{array}{c}\text { Participation } \\
(\%)\end{array}$ & Million Euros & $\begin{array}{c}\text { Participation } \\
(\%)\end{array}$ & Million Euros & $\begin{array}{c}\text { Participation } \\
(\%)\end{array}$ \\
\hline Cash and balances with CBK & 241.9 & 12.5 & 268.1 & 12.1 & 265.3 & 10.6 \\
\hline $\begin{array}{l}\text { Balance with commercial } \\
\text { banks }\end{array}$ & 286.7 & 14.9 & 351.6 & 15.8 & 319.5 & 12.8 \\
\hline Securities & 34.1 & 1.8 & 114.0 & 5.1 & 205.6 & 8.2 \\
\hline Loans and leases & $1,280.9$ & 66.5 & $1,404.6$ & 63.3 & $1,624.9$ & 65.0 \\
\hline Fixed assets & 40.1 & 2.1 & 42.6 & 1.9 & 45.0 & 1.8 \\
\hline Other assets & 43.5 & 2.3 & 37.8 & 1.7 & 40.8 & 1.6 \\
\hline Total & $1,927.1$ & 100.0 & $\mathbf{2 , 2 1 8 . 8}$ & 100.0 & $\mathbf{2 , 5 0 1 . 1}$ & 100.0 \\
\hline
\end{tabular}

\section{Source: CBK (2011)}

By analyzing the data in the table above we can see that the banking system in Kosovo has had a steady rise in recent years, which is a positive indicator and good news for SMEs, as well as the opportunity to their funding from external sources.

Based on data from the Central Bank, commercial banks' lending activity continues to represent one of the main sources of financing for consumption and investments. After recovery of the financial markets in foreign economies and improved perception of commercial banks for the business environment in Kosovo has had a trend of accelerated growth of loans issued for SMEs. The total amount of loans issued by banks in Kosovo until June 2011 amounted to EUR 1.6 billion or $34.3 \%$ of GDP. 
Despite the rapid growth of loans to enterprises, their share in total loans in June 2011 was lower compared to June 2010. The share of loans to enterprises in June 2011 was $69.2 \%$, compared with $70.6 \%$ in the same period of the previous year. Meanwhile, loans to households continued to increase their participation, reaching $29.7 \%$ in June 2011 compared with 29.4\% in June 2010 (CBK 2012).

Structure of loans issued to enterprises, according to economic activity continues to be similar to previous periods. Loans to the services sector continued to dominate the overall structure of loans to enterprises with a share of $71.4 \%$. Within the framework of the services sector loans, the majority continues to consist of loans issued to the trade sector, which in June 2011 represented 52.5\% of total loans (CBK, 2012).

Loans to the retail sector in June 2011 recorded annual growth of $21.3 \%$ reaching a value of 589.5 million Euros. Also, lending to enterprises providing financial services amounted to 24.8 million Euros, which represents an annual increase of $37.0 \%$. Loans to the manufacturing sector were characterized by a slower trend growth during this period. In June 2011, loans to the manufacturing sector recorded annual growth of just $4.8 \%$, compared with growth of $20.6 \%$ in June 2010. Within the industrial sector, except mining which increased both in volume and in share to total loans, lending to all other sectors slowed down. Loans for the mining, despite their small share in total loans to enterprises (1.1\%) recorded an annual growth of $61.0 \%$ in June 2011, reaching a value of 12.7 million Euros. Reducing the share of loans allocated to the agriculture sector was a result of the slowdown in growth in the volume of these loans. Loans to agriculture increased by only $0.8 \%$ in June 2011 , compared with growth of $2.2 \%$ in June 2010 . The value of total loans to agriculture in June 2011 amounted to 40.1 million Euros. (CBK, 2012).

\section{Conclusions}

The purpose of this study was to identify factors that influence the growth and development of SMEs in Kosovo with particular emphasis on the impact of external factors and bank loans. The conclusions are derived based on the analysis of findings in previous chapters.

A number of factors affecting the growth and development of SMEs in Kosovo have been identified in this research. Just as the literature shows, access to finance is one of the main barriers for small and medium enterprises. This is especially highlighted in the new enterprises, or those that are under establishment according to research that constitute the largest number of enterprises in Kosovo with $98.37 \%$ of the total enterprises.

In addition the data from reports for the loans issued by banks show that loans issued to the trade sector lead by $52.5 \%$, while for the industrial sector including the production and construction, issued loans amount to $25 \%$. This gives us the understanding that sectors that are very important for the economic development of a country, such as production and agriculture, face difficulties in providing funding sources, where banks have the leading role, as consequence of the absence of other funding options in Kosovo. These findings are supported by empirical data generated by this research.

For the purpose of comparing and measuring the weight of the funding or access to finance as a factor, the research included other factors too such as competition, corruption and government policies. According to the research, competition is not considered as a negative, but rather, the unfair competition is seen as a barrier to enterprise development. In addition, as a result of lack of funding and the proper access to funding, respondent's estimate that it leads to increased corruption, which in this case is consistent with the theoretical aspects and literature review in this research.

Lack of capital market and other financing alternatives forces enterprises in most cases to be oriented to commercial banks for loans. Therefore, we can conclude that external factors such as access to finance, competition, corruption, and government policies have very impact in the development of SMEs in Kosovo. Also, in this context, it is very clear that despite the problems and obstacles in loans, bank loans play an important role in the development of SMEs in Kosovo However, bank and nonbank financial institutions requirements to business are more suited to expanding of existing businesses and are less favorable for the establishment of new businesses.

\section{References}

World Bank, (2012). "Doing business in a more transparent world". WB, Washington.

Central Bank of Kosovo, (2011). "Financial Stability Report No.2". Pristine: CBK

Central Bank of Kosovo, (2011). "Payment Systems and Settlements in Kosovo". Pristine.

Central Bank of Kosovo, (2009). Annual Report. Pristine, (2001-2008).

Bryman, A. and Bell, E. (2007). Business Research Methods, 2nd ed., Oxford: Oxford University Press.

Center for Financial Training, (2003). Banking and Financial Systems.USA. 
Chowdri Siddartha H. (2004). "Downscaling Institutions and Competitive Microfinance Markets: Reflections and Case - Studies from Latin America", August 2004 Edited by Alex Silva, Omtrix Inc., Commissioned by CALMEADOW

Conger, Lucy, (2003). "To Market, To Market", Microenterprise Americas. Inter American Development Bank.

Davidsson, P, Delmar, F, \& Wiklund, J (Eds.), (2006). Entrepreneurship and the Growth of Firms. Edward Elgar Publishing, United Kingdom, England, Cheltenham

Delfiner, Miguel, Peron, Silvana, (2007). Commercial Banks and Microfinance, MPRA Paper 10229.

EU Commission, (2003). Recommendation 2003/361/EC, Official Journal L 124 of 20.05.2003.

Kosovo Agency of Statistics, (2011). "Statistical Report on Enterprises in Kosovo". Pristine: KAS.

Ghauri, P., Grønhaug, K. and Kristianslund, I., (1995). Research methods in business studies: A practical study. New York: Prentice Hall.

Hilary, R., (2000). Small and medium sized enterprises and the business environment. Greenleaf Publishing.

Heine, C. (2009). Has the financial crisis induced a credit crunch for small and medium sized companies? Grin Verlag.

Instituti Riinvest, (2001). Financimi i zhvillimit te NVM-ve. Pristine: Instituti Riinvest.

Joanna Ledgerwood, (1999). Microfinance handbook: An institutional and financial perspective, Washington, D.C World Bank

Jethnani, H. (2010). Elite SME's defy recession odds. Retrieved from http://www.asiaone.com/Business/SME+Central/Prime+Movers/ Story/A1Story20100122-193700.html

Kaibori, S. (2001). Development of small and medium sized enterprises. Retrieved from http://www.esri.go.jp/en/tie/russia/russia7-e.pdf

Lind, P. (2005). "Competitiveness through increased Added Value: A Challenge for Developing Countries", Journal Comparative International Management, Vol. 8, No. 1, pp. 42-57.

Lind, P. (2009). "Innovation as a growth strategy for SMEs", lecture in SME Management in a global context, autumn 2009, 1 October, Gotland University, Visby.

Mauring, Frode et all, (2007). Development \& Transition. Kosovo Edition "Private Sector Development".

Nichter, S. and Goldmark, L., (2009). "Small Firm Growth in Developing Countries", World Development, Vol. 37, No. 9, pp. 1453-1464.

OSMEP, (2008). "Situation and Structural Indicators of SMEs in 2008 and 5-Year Changes", White Paper on SMEs 2008 and Trends 2009.

Poblete, L. \& Grimsholm, E. (2010). Internal and external factors hampering SME growth. Master in International Management. Gotland University

Qeveria e Kosovës, (2011). "Strategjia për zhvillimin e NMV-ve në Kosovë". Pristine: Qeveria e Kosovës

SBA, (2009). The small business economy. A report to the President. Retrieved from http://archive.sba.gov/advo/research/sb_econ 2009.pdf

Sha, S. (2005). An investigation into problems facing medium sized enterprises in achieving growth in the Eastern Cape. Retrieved from http://eprints.ru.ac.za/288/1/Sha-TR06-146.pdf

Shelagh Heffernan, (2005). Modern Banking, Wiley.

Tax Administration of Kosovo (2011): Annual report of the SME.

The Independent, (2009). Small businesses, recession busters. Retrieved from http://www.independent.co.uk/news/business/sme/smallbusinesses-recessionbusters-1817683.html

Koch, Timothy, W. and S. Scott MacDonald, (2008). Bank Management, South-Western College Pub, International Edition edition. 